\title{
Activation of Cultured Rat Hepatic Lipocytes by Kupffer Cell Conditioned Medium Direct Enhancement of Matrix Synthesis and Stimulation of Cell Proliferation via Induction of Platelet-derived Growth Factor Receptors
}

Scott L. Friedman and Michael J. P. Arthur

The Liver Core Center and Medical Service, San Francisco General Hospital, and Department of Medicine, University of California, San Francisco, California 94110

\begin{abstract}
Hepatic lipocytes appear to be central to the pathogenesis of hepatic fibrosis, undergoing activation during inflammation to a matrix-producing, proliferative cell type. We have studied the activation process in culture by examining the response of lipocytes to conditioned medium from hepatic macrophages (Kupffer cells). Lipocytes exposed to Kupffer cell medium (KCM) exhibited cellular and nuclear enlargement associated with up to a threefold increase in collagen and total protein synthesis per cell. Cell proliferation was also stimulated as measured by $\left[{ }^{3} \mathrm{H}\right]$ thymidine incorporation and direct cell counting. The latter effect was serum dependent and inhibited by antibodies to platelet-derived growth factor (PDGF). Proliferation could be stimulated by recombinant PDGF, but only after preincubation of cells with KCM. These findings suggested that KCM was eliciting expression of the PDGF receptor in lipocytes, and this was confirmed by immunoblot analysis with antibodies to the PDGF receptor. DNA synthesis in lipocytes exposed to KCM occurred at $48 \mathrm{~h}$, which reflected the time required for PDGF receptor expression (24 h) plus initiation of $\left.{ }^{3} \mathrm{H}\right]$ thymidine incorporation $(24 \mathrm{~h})$. These results indicate that KCM has multiple stimulatory effects on cultured lipocytes similar to activation of these cells observed in vivo.
\end{abstract}

\section{Introduction}

Activation and accumulation of lipocytes (Ito, stellate, fatstoring, and vitamin A-storing cells) after liver injury are morphologic hallmarks of ongoing hepatic fibrogenesis $(1,2)$. Activation is characterized by prominent rough endoplasmic reticulum, reduced intracellular vitamin A content, and increased pericellular collagen $(1,3,4)$. Accumulation may result from both local proliferation and directed migration (5).

Primary culture of lipocytes is an important tool for exam-

Preliminary reports of portions of this work have been published as abstracts (1987. Hepatology [Baltimore]. 7:1048 [Abstr.]; and 1988. Hepatology [Baltimore]. 8:1231 [Abstr.]).

Dr. Arthur's current address is Department of Medicine II, LD68, South Laboratory and Pathology Block, Southampton General Hospital, Tremona Road, Southampton, Hants, S09 4XY, UK.

Address correspondence to Dr. S. L. Friedman, Liver Center Laboratory, Building 40, Room 4102, San Francisco General Hospital, San Francisco, CA 94110.

Received for publication 30 June 1989 and in revised form 9 August 1989.

J. Clin. Invest.

(c) The American Society for Clinical Investigation, Inc.

0021-9738/89/12/1780/06 \$2.00

Volume 84, December 1989, 1780-1785 ining mechanisms of activation, which have thus far been poorly understood. Cultured lipocytes on uncoated plastic display a matrix phenotype remarkably similar to that of fibrotic liver $(6,7)$, producing collagens (type I $>$ type IV $>$ type III), laminin, and sulfated glycosaminoglycans (dermatan $>$ chondroitin $>$ heparan sulfates; 8-10). Moreover, their relationship to endothelium in situ and positive staining for des$\min (11,12)$ suggest that they belong to a group of organ-specific pericytes (capillary smooth muscle cells) that includes kidney mesangial cells (13), lung fibroblasts (14), and retinal capillary pericytes (15).

We have focused on the potential activation of cultured lipocytes by hepatic macrophages (Kupffer cells) because tissue macrophage products in lung and other tissues are potent modulators of mesenchymal proliferation and matrix production (16-19). For example, exaggerated release of platelet-derived growth factor (PDGF) ${ }^{1}$ by lung macrophages may be an important mechanism of fibroblast proliferation in chronic idiopathic pulmonary fibrosis (20). The involvement of PDGF in hepatic fibrogenesis has not been studied.

PDGF is a $28,000-35,000 \mathrm{~mol}$ wt peptide that can exist as either A,A or B,B homodimers or A,B heterodimer (21). It exerts its biologic effects by binding to specific cellular receptors. The receptor for PDGF is a $160,000-180,000 \mathrm{~mol}$ wt anionic glycosylated protein belonging to the superfamily of Ig receptors that includes the receptor protein for colony-stimulating factor (CSF-1/c-fms; 22). It is a transmembrane molecule whose intracellular portion contains a tyrosine kinase domain (23). Ligand binding activates an array of intracellular events, including phosphorylation of the receptor itself (24). Modulation of the response to PDGF could thus be regulated either by the availability of PDGF, by the level of expression of PDGF receptor, or by the specificity of the receptor for a given PDGF isoform. To date, few examples of modulation of the level of PDGF receptor have been identified, although this is a potentially important mode of regulation.

We report here that conditioned medium from primary cultures of rat Kupffer cells has broad stimulatory activity towards lipocytes, causing transition to an activated appearance, enhanced protein and collagen synthesis, and induction of responsiveness to PDGF. The acquisition of responsiveness to PDGF is due to de novo expression of the receptor for PDGF.

\section{Methods}

Cell culture. Lipocytes and Kupffer cells were isolated from male retired breeder Sprague-Dawley rats $(450-600 \mathrm{~g})$ by in situ perfusion and

1. Abbreviations used in this paper: $\mathrm{KCM}, \mathrm{Kupffer}$ cell medium; PDGF, platelet-derived growth factor. 
Larex density gradient centrifugation as previously described (25), except that Kupffer cells were further purified by centrifugal elutriation (26). Lipocytes were $>99 \%$ pure as assessed by specific fluorescent markers for lipocytes, endothelial cells, and Kupffer cells $(25,27)$. Kupffer cell isolates were $>90 \%$ pure, the main contaminant being lipocytes (27). Cells were plated on uncoated plastic at a density of $10^{5}$ cells/well in 24-well plates or 1.5-1.8 $\times 10^{6}$ cells/dish in $35-\mathrm{mm}$ dishes, and maintained in medium 199 with $20 \%$ serum (10\% horse/10\% calf; Flow Laboratories, Inc., McLean, VA) except where indicated. Serum-free medium 199 contained 0.5\% BSA (Sigma Chemical Co., St. Louis, MO). Medium was changed $24 \mathrm{~h}$ after plating and every $48 \mathrm{~h}$ thereafter. All studies of cultured lipocytes used cells in primary culture for 4-5 d, maintained in the presence of serum. Lipocytes were photographed with an inverted microscope (Diaphot; Nikon Inc., Garden City, NY) using ASA 400 film (Ilford, Cheshire, UK). Balb c/3T3 cells were grown in DME with $10 \%$ calf serum, penicillin, and streptomycin on uncoated plastic 6-well plates and harvested $5 \mathrm{~d}$ after plating (28).

Conditioned medium for Kupffer cells was harvested every $48 \mathrm{~h}$, beginning $96 \mathrm{~h}$ after plating, pooled with previous collections, and replaced by fresh medium. For serum-free incubations cells were washed twice with serum-free medium before conditioning. Recovered medium was filtered $(0.2 \mu \mathrm{m})$ and frozen at $-20^{\circ} \mathrm{C}$. Kupffer cells were maintained for up to $28 \mathrm{~d}$ in primary culture as a source of conditioned medium.

Measurement of collagen and protein synthesis. Collagen and total protein synthesis were determined as the incorporation of $\left[{ }^{3} \mathrm{H}_{2.3,4.5}\right]$ proline into peptide-bound proline and hydroxyproline, respectively (29). Cells in 35-mm dishes were incubated $24 \mathrm{~h}$ with radiolabel and cells and media were harvested with protease inhibitors at $4^{\circ} \mathrm{C}$, dialyzed to remove unincorporated radioactivity, hydrolyzed, and analyzed by amino acid analysis and liquid scintillation spectrometry, all as previously described (25). Final data were normalized for cell number by measuring cellular DNA content determined fluorimetrically (30). DNA content of lipocytes correlated closely with cell number ( $r$ $=0.9934$ ) in resting and proliferating cells (25). In some experiments total protein synthesis was assessed as incorporation of $\left[{ }^{3} \mathrm{H}\right]$ leucine into TCA-insoluble proteins (31). For these studies, cells in 24-well plates were washed in L-15 salts, then incubated for $2 \mathrm{~h}$ in serum-free medium 199 containing $50 \mu \mathrm{Ci} / \mathrm{ml}\left[{ }^{3} \mathrm{H}\right]$ leucine. The medium was discarded and cells were washed three times in cold $10 \%$ TCA, dried in cold ethanol/ether (1:1), and incubated for $30 \mathrm{~min}$ in $2 \% \mathrm{Na}_{2} \mathrm{CO}_{3}$ in
$0.1 \mathrm{~N} \mathrm{NaOH}$ (Lowry reagent). The cell layers were harvested after sonication, neutralized with glacial acetic acid, and suspended in Ecolite (ICN Radiochemicals, Irvine, CA) for quantitation by liquid scintillation spectrometry. Final data were expressed as disintegrations/ minute $\left[{ }^{3} \mathrm{H}\right]$ leucine per well per $2 \mathrm{~h}$.

Measurement of DNA synthesis and cell proliferation. Replicative DNA synthesis by lipocytes was measured as incorporation of $\left[{ }^{3} \mathrm{H}\right]-$ thymidine (32) with modifications (33). In initial experiments (Fig. 3) data were normalized for DNA content (30); thereafter they were expressed as disintegrations/minute $\left[{ }^{3} \mathrm{H}\right]$ thymidine per well. Independent assessment of cell proliferation was determined by direct cell counting using an automated cell counter (Sysmex; TOA Medical Electronics, Kobe, Japan). Recombinant PDGF ( $v$-sis) was purchased from Amgen Biologicals (Thousand Oaks, CA), anti-PDGF from Collaborative Research Inc. (Lexington, MA), and nonimmune IgG from Cappell Laboratories (Cochranville, PA).

Immunoblot analysis of PDGF receptor expression. Lipocytes maintained in $35-\mathrm{mm}$ plates in the presence or absence of conditioned medium were harvested in Ripand/Triton/BSA buffer containing 10 $\mathrm{mM}$ Tris- $\mathrm{HCl}$ (pH 7.4), $50 \mathrm{mM} \mathrm{NaCl}, 50 \mathrm{nM} \mathrm{NaF}, 30 \mathrm{mM}$ sodium pyrophosphate, $100 \mu \mathrm{M}$ orthovandate, $5 \mathrm{mM}$ EDTA, $1 \%$ Triton $\mathrm{X}-100,1 \mathrm{mg} / \mathrm{ml} \mathrm{BSA}$, and $1 \mathrm{mM}$ PMSF, all as previously described (34). The extracts were centrifuged at $10,000 \mathrm{~g}$ at $4^{\circ} \mathrm{C}$ for $15 \mathrm{~min}$, resuspended in Laemmli buffer, incubated at $95^{\circ} \mathrm{C}$ for $5 \mathrm{~min}$, then separated by SDS-PAGE. After electrophoresis, proteins were transferred to nitrocellulose filters and immunoblotted using a rabbit receptor antibody (28) followed by a horseradish peroxidase-conjugated goat anti-rabbit IgG (Bio-Rad Laboratories, Richmond, CA).

Statistical methods. Data were analyzed by the $t$ test for paired data.

\section{Results}

Effects of Kupffer cell conditioned medium KCM on lipocyte morphology, collagen, and total protein synthesis. Lipocytes exposed to KCM demonstrated marked nuclear enlargement, cytoplasmic spreading, and apparent loss of retinoid vesicles (Fig. 1). These changes were not present in cells exposed to fresh (control) medium and occurred independently of serum. They could first be observed at $48 \mathrm{~h}$.
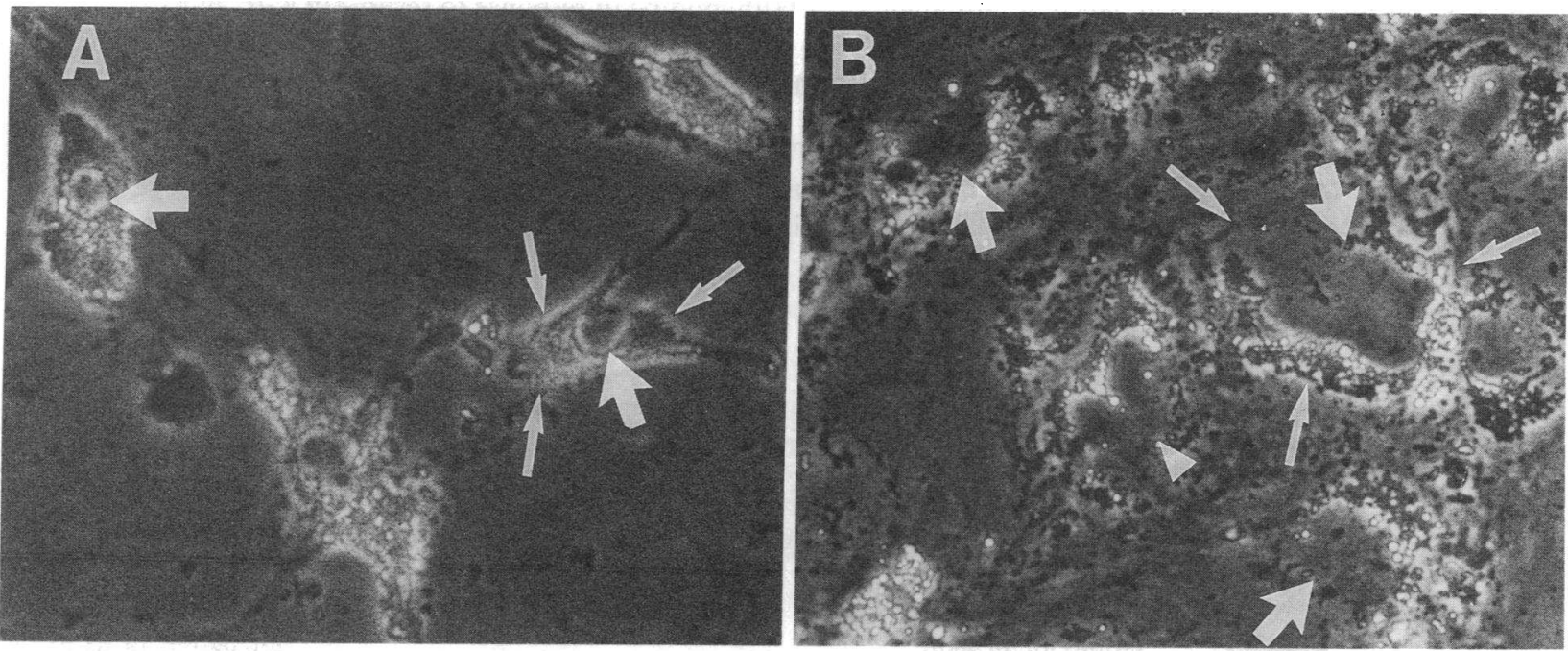

Figure 1. Effects of KCM on lipocyte morphology. Lipocytes in primary culture at equal plating density were exposed to control medium or KCM (both with serum) for days 3-6 as described in Methods. $A$, Cells maintained in control medium have a compact cytoplasm (thin white arrows) containing retinoid droplets, small nuclei (thick white arrows), and distinct cell borders. B, Cells exposed to KCM have expanded cytoplasm (thin white arrows) with an apparent decrease in retinoid droplet size and greatly enlarged nuclei (thick white arrows). A dividing cell is evident (arrowhead). Each panel has an equal number of cells. $\times 712$. 


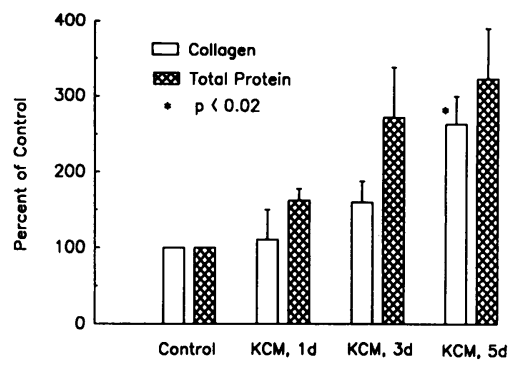

Figure 2. Collagen and total protein synthesis in lipocytes exposed to $\mathrm{KCM}$. Cells grown in 35-mm culture dishes for $3 \mathrm{~d}$ were exposed to either control medium (containing 20\% serum) or serum-containing $\mathrm{KCM}$ for 1,3 , or $5 \mathrm{~d}$ and analyzed for collagen and protein synthesis as described in Methods. Data from three experiments (each in triplicate) were normalized for DNA content per plate as disintegrations/minute $\left[{ }^{3} \mathrm{H}\right]$ proline per microgram DNA and are depicted here as percent of synthesis in control cultures. Bars, Mean \pm SEM.

The morphologic response to KCM was accompanied by increased fibrogenesis. Synthesis of both collagen and total cellular protein normalized for cell number increased progressively, reaching three times the control level after $5 \mathrm{~d}$ (Fig. 2). These changes were not serum dependent, in that total protein synthesis increased twofold in KCM-treated lipocytes under serum-free conditions (in disintegrations/min $\left[{ }^{3} \mathrm{H}\right]$ leucine per well for three experiments \pm SD): control lipocytes, $1,970 \pm 74$; KCM-treated lipocytes, 4,060 $\pm 71(P<0.03)$. Hepatocyteconditioned medium, like fresh medium, had no effect on lipocyte morphology, protein synthesis, or DNA synthesis (data not shown).

Effects of KCM on lipocyte DNA synthesis. DNA synthesis per cell increased strikingly with KCM-treated lipocytes in the presence of serum as assessed by incorporation of $\left[{ }^{3} \mathrm{H}\right]-$ thymidine (Fig. 3). This incorporation was inhibited $90-95 \%$ ( $n=4$, data not shown) by $10 \mathrm{mM}$ hydroxyurea, confirming that DNA synthesis was replicative. Enhanced DNA synthesis was accompanied by a progressive increase in cell number with increasing KCM exposure (Table I).

Mechanism of KCM-induced lipocyte proliferation. In the above studies KCM contained $20 \%$ serum. When KCM was collected under serum-free conditions it failed to stimulate proliferation. However, when serum was added back to KCM DNA synthesis could be stimulated, suggesting that a serum factor was essential for this effect of KCM. We directed our attention to PDGF as the likely serum factor, in part because of evidence that PDGF may play a role in fibrosis of the lung and kidney $(17,20)$. Preincubation of serum-containing KCM with polyclonal antibody to PDGF blocked DNA synthesis

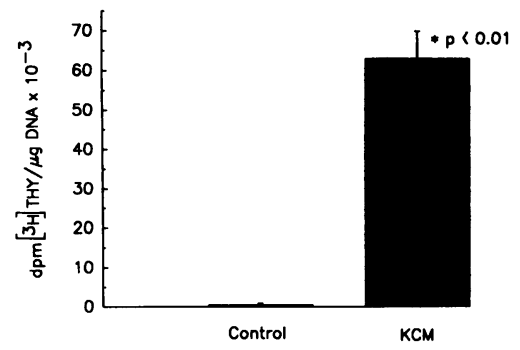

Figure 3. Effects of KCM on lipocyte DNA synthesis. Lipocytes in primary culture in 24well uncoated plates for $4 \mathrm{~d}$ were incubated in control medium or KCM (both with serum) for an additional $48 \mathrm{~h}$ and analyzed for DNA synthesis by 4-h incubation with $\left[{ }^{3} \mathrm{H}\right]$ thymidine. Data from three experiments, each normalized for cellular DNA content, are shown. Bars, Mean \pm SEM.
Table I. Effect of KCM on Lipocyte Number

\begin{tabular}{lcc}
\hline & $\begin{array}{c}\text { Cells per well } \\
(\text { mean } \pm \text { SD) }\end{array}$ & $\begin{array}{c}\text { Percent increase } \\
\text { (mean) }\end{array}$ \\
\hline Control & $\times 10^{4}$ & \\
KCM $\times 2 \mathrm{~d}$ & $9.3 \pm 1.5$ & - \\
$\mathrm{KCM} \times 5 \mathrm{~d}$ & $13.7 \pm 0.5^{*}$ & 32.1 \\
& $15.7 \pm 0.5^{\ddagger}$ & 68.8 \\
\hline
\end{tabular}

Lipocytes in primary culture for $4 \mathrm{~d}$ were incubated in either plain (control) medium or KCM for 2 or $5 \mathrm{~d}$ (all with $20 \%$ serum), harvested in L-15 salts, and counted by automated cell counter. Data shown represent duplicate determinations of three cultures for each condition.

${ }^{*} P<0.02 ;{ }^{\ddagger} P<0.01$

$76-93 \%(n=3$; Fig. 4); in addition, serum-free KCM to which pure PDGF was added stimulated DNA synthesis (Fig. 5). PDGF alone in the absence of KCM had no effect on DNA replication in lipocytes (three experiments in triplicate, data not shown).

In aggregate, the results suggested that KCM induced responsiveness to PDGF, and that PDGF was not produced by Kupffer cells but had to be provided exogenously. A potential explanation was that KCM induced expression of PDGF receptors. We examined this possibility by performing immunoblot analysis of lipocyte extracts (Fig. 6). Receptor for PDGF was not detectable in resting lipocytes in the presence of serum, but was clearly apparent within $24 \mathrm{~h}$ after treatment with KCM (with or without serum). The cells displayed both mature and precursor forms of the receptor, of molecular weights nearly identical to those of Balb c/3T3 cells. Furthermore, cells stimulated to express PDGF receptor by KCM in the absence of serum began to incorporate $\left[{ }^{3} \mathrm{H}\right]$ thymidine $24 \mathrm{~h}$ after addition of serum (Fig. $7 \mathrm{~A}$ ). In lipocytes exposed only to serum-containing KCM, DNA synthesis occurred at $48 \mathrm{~h}$ (Fig. $7 \mathrm{~B}$ ); this interval corresponded to the time required for expression of the PDGF receptor ( $24 \mathrm{~h}$ ) followed by initiation of $\left[{ }^{3} \mathrm{H}\right]$ thymidine in response to serum (PDGF; $24 \mathrm{~h}$ ).

\section{Discussion}

The cellular responses to liver injury have been well characterized morphologically. Activation of hepatic lipocytes is consistently observed regardless of the hepatotoxin. Recruitment

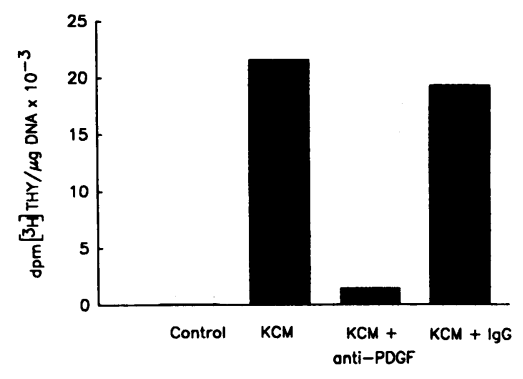

Figure 4. Effect of antiPDGF on KCM-induced lipocyte DNA synthesis. Lipocytes in early primary culture were exposed for $48 \mathrm{~h}$ to either control medium, KCM, KCM preincubated for $2 \mathrm{~h}$ at $37^{\circ} \mathrm{C}$ with anti-PDGF $(50 \mu \mathrm{g} / \mathrm{ml})$, or $\mathrm{KCM}$

preincubated under identical conditions with nonimmune IgG (50 $\mu \mathrm{g} / \mathrm{ml})$, and assessed for incorporation of $\left[{ }^{3} \mathrm{H}\right]$ thymidine as described in Methods. A single experiment performed in triplicate is shown. In three separate experiments the range of inhibition by anti PDGF was 76-93\%. 


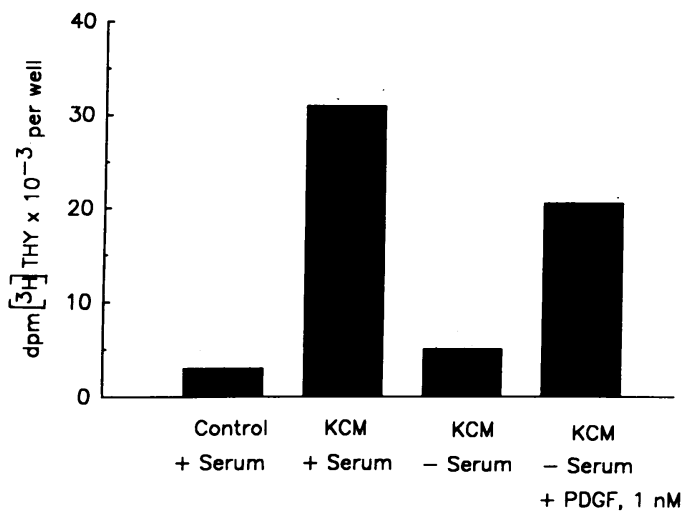

Figure 5. Combined effect of KCM and PDGF on lipocyte DNA synthesis. 4-d-old lipocytes in primary culture were incubated for $\mathbf{4 8}$ $h$ in nonconditioned serum-containing medium (control), serumcontaining KCM, or serum-free KCM with or without PDGF. Uptake of $\left[{ }^{3} \mathrm{H}\right]$ thymidine was assessed as in previous figures. Pure PDGF in the absence of KCM (not shown here) had no effect on $\left[{ }^{3} \mathrm{H}\right]-$ thymidine incorporation (see Results).

and activation of Kupffer cells are also prominent features of liver injury in man (35) and animals (26). The mechanisms underlying these events are not well understood.

We have demonstrated that conditioned medium from cultured Kupffer cells of normal rats stimulates hepatic lipocytes in a manner closely parallel to changes observed in hepatic fibrogenesis. Moreover, the activation occurs both by a direct effect on morphology and matrix synthesis and by an indirect effect of PDGF after induction of receptor expression for this growth factor. PDGF is an important mitogen and

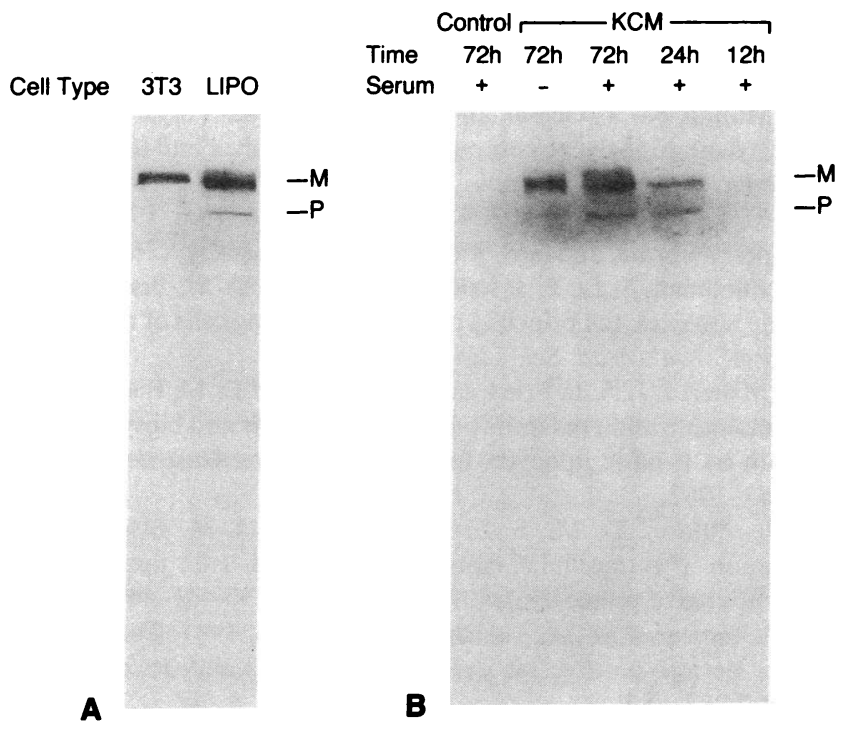

Figure 6. Effect of KCM on PDGF receptor expression. $A$, Plasma membrane extracts from Balb c/3T3 cells (positive control) or KCMtreated lipocytes were separated in SDS-PAGE, transferred to nitrocellulose, and blotted with antibody to the PDGF receptor as described in Methods. Both glycosylated mature $(M)$ and nonglycosylated precursor $(P)$ forms are evident in lipocytes. $B$, Equal numbers of lipocytes (3-3.5 $\times 10^{6}$ cells) in $35-\mathrm{mm}$ dishes were analyzed after incubation in plain medium (with serum) or KCM (with or without serum) for 12-72 h. Receptor expression is evident only in KCMtreated cells and occurs within $24 \mathrm{~h}$.

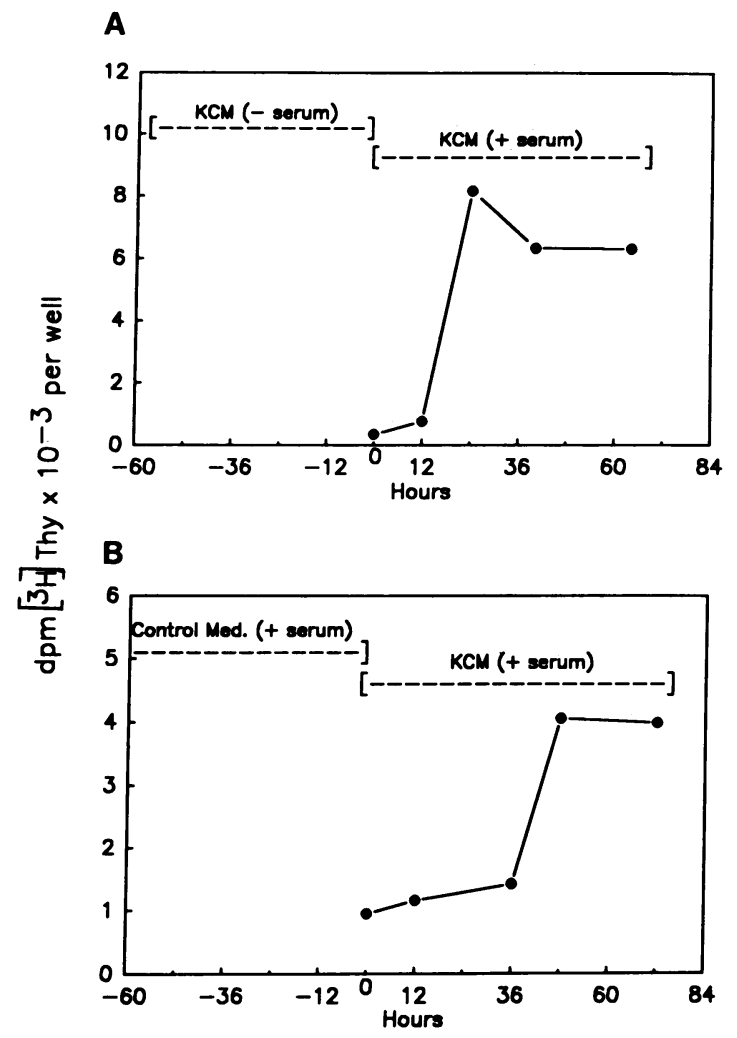

Figure 7. Time course of lipocyte DNA synthesis in response to KCM. $A$, Day 3 cells were pretreated for $48 \mathrm{~h}$ in serum-free KCM to induce PDGF receptor expression (see Fig. 6), serum was added at time 0 , and $\left[{ }^{3} \mathrm{H}\right]$ thymidine incorporation was assessed at the times indicated, as described in Methods. Incorporation of radiolabel began 12-24 h after addition of serum. Data shown represent triplicate determinations at each time point. $B$, Day 5 cells maintained in plain medium were exposed to serum-containing KCM and assayed at $12,36,48$, and $72 \mathrm{~h}$. In the absence of pretreatment $\left[{ }^{3} \mathrm{H}\right]$ thymidine incorporation began 36-48 $\mathrm{h}$ after addition of KCM. Data shown represent triplicate determinations at each time point.

chemoattractant for vascular smooth muscle cells and probably contributes to cell proliferation in atherosclerosis and fibrogenesis of lung $(19,20)$. Its potential participation in hepatic fibrogenesis has not previously been reported. While lipocytes stimulated by KCM are responsive to PDGF, the source of this peptide in liver fibrogenesis is uncertain. Under the present experimental conditions Kupffer cells, unlike lung macrophages, fail to release biologically active PDGF, since addition of serum or recombinant PDGF was required to induce thymidine incorporation in KCM-treated lipocytes. In addition, serum-free $\mathrm{KCM}$ failed to induce receptor phosphorylation in Balb c/3T3 cells (Escobedo, J., and S. Friedman, unpublished observations). It is possible that additional activation of Kupffer cells is required before PDGF release occurs. It is also possible that Kupffer cells release an isoform of PDGF not recognized by lipocytes. Alternatively, PDGF may derive from circulating platelets, which are present in hepatic inflammation (36).

The induction of PDGF receptor expression by macrophage-conditioned medium (KCM) is a potentially relevant mode of regulating PDGF responsiveness in vivo. Enhanced PDGF receptor expression accompanies vascular inflamma- 
tion of the kidney (37) and synovium (38). The PDGF receptor in membrane extracts of cultured lipocytes stimulated by $\mathrm{KCM}$ is similar in molecular weight to that of Balb c/3T3 cells. Moreover, its expression occurs independently of serum, but is enhanced by serum. The possibility that KCM merely accelerates regeneration of extracellular receptors removed during cell isolation is excluded by the absence of the receptor precursor in untreated cells. This lower molecular weight form exists only intracellularly and would not be accessible to enzymes used during isolation.

Recent studies suggest that the PDGF receptor can exist as either an $\alpha \alpha(39), \alpha \beta(23,40)$, or $\beta \beta$ form (41). Our study does not establish which form of the receptor is expressed in lipocytes since the antibody we used does not distinguish receptor forms, and also because the responsiveness of lipocytes to recombinant PDGF BB homodimer could be mediated by more than one receptor type. In our system PDGF BB homodimer (v-sis) largely reproduced the mitogenic effect of serum; the slightly lower magnitude of response may reflect a higher concentration of PDGF in serum-containing medium (42). Alternatively, KCM might also induce receptor expression for other mitogens present in serum.

The ability to modulate the level of PDGF receptors in cultured cells has only recently been observed. Terracio et al. have shown that freshly isolated myometrial cells do not express PDGF receptors, whereas receptors are present on cells in early primary culture on uncoated plastic (43). The enhanced expression of PDGF receptors may in part be a spontaneous response to the culture substratum. We have recently demonstrated that isolated lipocytes maintained on a basement membrane gel remain morphologically and functionally quiescent, whereas cells on uncoated plastic are activated and begin proliferating in the presence of serum after 10-12 $\mathrm{d}$ in primary culture (33). It seems likely, therefore, that lipocytes in prolonged primary culture $(25,33)$ or after subculture $(44)$ proliferate in response to serum because expression of the receptor has occurred. This possibility underscores the importance of performing studies on lipocytes in early primary culture or on a basement membrane gel if the goal is to recapitulate the response of quiescent lipocytes to activating stimuli. These results also suggest that expression of PDGF receptor results from an interplay of soluble stimuli (i.e., KCM) and extracellular matrix.

The enhancement of lipocyte matrix synthesis by KCM has been observed previously $(45,46)$. The proportionate increase in collagen and total protein synthesis in our study suggests that this activation process is generalized and may result in enhanced synthesis of other matrix constituents such as laminin and proteoglycans. Moreover, it supports the contention that lipocytes are the principal matrix-producing cell in hepatic fibrogenesis $(8,47)$. The mechanism for increased matrix synthesis is not apparent from our experiments; however, in contrast to the proliferative response, it is not PDGF dependent.

The activating factor(s) in KCM responsible for these effects are not fully characterized. Our preliminary findings suggest that both matrix-stimulating and receptor-inducing activity reside in a single low molecular weight species (48) that is distinct from any previously characterized growth factors.

In summary, we have presented evidence that $\mathrm{KCM}$ enhances lipocyte matrix production and stimulates proliferation via induction of PDGF receptors. These results suggest that
Kupffer cell-mediated lipocyte activation may be an important mechanism of hepatic fibrogenesis.

\section{Acknowledgments}

The authors thank Dr. J. Escobedo and Dr. L. T. Williams and Dale Milfay for PDGF receptor immunoblot analysis of lipocytes, Glenn Yamasaki for lipocyte and Kupffer cell isolation, Dr. Brent Tetri for his useful suggestions, Janet Doherty for manuscript preparation, and Dr. D. M. Bissell and Dr. J. Escobedo for their thoughtful reviews of the manuscript.

This work was supported in part by United States Public Health Service grants DK-37340, DK-31198, IP-50 DK-26743, and FO5 TW-03726 from the National Institutes of Health, and by funds (to Dr. Arthur) from the Medical Research Council of Great Britain, the American Liver Foundation, and the Smith and Nephew Foundation of Great Britain.

\section{References}

1. Minato, Y., Y. Hasumura, and J. Takeuchi. 1983. The role of fat-storing cells in Disse space fibrogenesis in alcoholic liver disease. Hepatology (Baltimore). 3:559-566.

2. Okanoue, T., E. J. Burbige, and S. W. French. 1983. The role of the Ito cell in perivenular and intralobular fibrosis in alcoholic hepatitis. Arch. Pathol. Lab. Med. 107:459-463.

3. Kent, G., S. Gay, T. Inouye, R. Bahu, O. T. Minick, and H. Popper. 1976. Vitamin A-containing lipocytes and formation of type III collagen in liver injury. Proc. Natl. Acad. Sci. USA. 73:3719-3722.

4. Takahara, T., T. Kojima, C. Miyabayashi, K. Inoue, H. Sasaki, Y. Muragaki, and A. Ooshima. 1988. Collagen production in fat-storing cells after carbon tetrachloride intoxication in the rat: immunoelectron microscopic observation of type I, type III collagens, and prolyl hydroxylase. Lab. Invest. 59:509-521.

5. Enzan, H. 1985. Proliferation of Ito cells (fat-storing cells) in acute carbon tetrachloride liver injury: a light and electron microscopic autoradiographic study. Acta Pathol. Jpn. 35:1301-1308.

6. Murata, K., Y. Ochiai, and K. Akashio. 1985. Polydispersity of acidic glycosaminoglycan components in human liver and the changes at different stages in liver cirrhosis. Gastroenterology. 89:1248-1257.

7. Rojkind, M., M.-A. Giambrone, and L. Biempica. 1979. Collagen types in normal and cirrhotic liver. Gastroenterology. 76:710-719.

8. Friedman, S. L., F. J. Roll, J. Boyles, and D. M. Bissell. 1985. Hepatic lipocytes: the principal collagen-producing cells of normal rat liver. Proc. Natl. Acad. Sci. USA. 82:8681-8685.

9. Maher, J. J., S. L. Friedman, F. J. Roll, and D. M. Bissell. 1988. Immunolocalization of laminin in normal rat liver and biosynthesis of laminin by hepatic lipocytes in primary culture. Gastroenterology. 94:1053-1062.

10. Arenson, D. M., S. L. Friedman, and D. M. Bissell. 1988. Formation of extracellular matrix in normal rat liver: lipocytes as a major source of proteoglycan. Gastroenterology. 95:441-447.

11. Tsutsumi, M., A. Takada, and S. Takase. 1987. Characterization of desmin-positive rat liver sinusoidal cells. Hepatology (Baltimore). 7:277-284.

12. Takase, S., M. A. Leo, T. Nouchi, and C. S. Lieber. 1988. Desmin distinguishes cultured fat-storing cells from myofibroblasts, smooth muscle cells and fibroblasts in the rat. J. Hepatol. (Amst.). 6:267-276.

13. Schlondorff, D. 1987. The glomerular mesangial cell: an expanding role for a specialized pericyte. FASEB (Fed. Am. Soc. Exp. Biol.) J. 1:272-281.

14. Bitterman, P. B., S. I. Rennard, and G. W. Hunninghake. 1982. Human alveolar macrophage growth factor for fibroblasts. J. Clin. Invest. 70:806-822.

15. Cohen, M. P., R. B. Frank, and A. A. Khalifa. 1980. Collagen 
production by cultured retinal capillary pericytes. Invest. Ophthalmol. \& Visual Sci. 19:90-94.

16. Bitterman, P. B., S. Adelberg, and R. G. Crystal. 1983. Spontaneous release of the alveolar macrophage-derived growth factor in the interstital lung disorders. J. Clin. Invest. 72:1801-1813.

17. Abboud, H. E., E. Poptic, and P. DiCorleto. 1987. Production of platelet-derived growth factorlike protein by rat mesangial cells in culture. J. Clin. Invest. 80:675-683.

18. Mornex, J. F., Y. Martinet, K. Yamauchi, P. B. Bitterman, G. R. Grotendorst, A. Chytil-Weir, G. R. Martin, and R. G. Crystal. 1986. Spontaneous expression of the c-sis gene and release of a platelet-derived growth factorlike molecule by human alveolar macrophages. J. Clin. Invest. 78:61-66.

19. Lovett, D. H., J. L. Ryan, and R. B. Sterzel. 1983. Stimulation of rat mesangial cell proliferation by macrophage interleukin $1 . J$. Immunol. 131:2830-2835.

20. Martinet, Y., W. N. Rom, G. R. Grotendorst, G. R. Martin, and R. G. Crystal. 1987. Exaggerated spontaneous release of plateletderived growth factor by alveolar macrophages from patients with idiopathic pulmonary fibrosis. N. Engl. J. Med. 317:202-209.

21. Ross, R., E. W. Raines, and D. F. Bowen-Pope. 1986. The biology of platelet-derived growth factor. Cell. 46:155-169.

22. Claesson-Welsh, L., A. Eriksson, A. Moren, L. Severinsson, B. Ek, A. Ostman, C. Betsholtz, and C. H. Heldin. 1988. cDNA cloning and expression of a human platelet-derived growth factor (PDGF) receptor specific for B-chain-containing PDGF molecules. Mol. Cell. Biol. 8:3476-3486.

23. Yarden, Y., J. A. Escobedo, W.-.J. Kuang, T. L. Yang-Feng, T. O. Daniel, P. M. Tremble, E. Y. Chen, and M. E. Ando. 1986. Structure of the receptor for platelet-derived growth factor helps define a family of closely related growth factor receptors. Nature (Lond.). 323:226-232.

24. Ek, B., B. Westermark, A. Wasteson, and C.-.H. Heldin. 1982. Stimulation of tyrosine-specific phosphorylation by platelet-derived growth factor. Nature (Lond.). 295:419-420.

25. Friedman, S. L., and F. J. Roll. 1987. Isolation and culture of hepatic lipocytes, Kupffer cells, and sinusoidal endothelial cells by density gradient centrifugation with Stractan. Anal. Biochem. 161:1233-1247.

26. Arthur, M. J. P., P. Kowalski-Saunders, and R. Wright. 1986. C parvum-elicited hepatic macrophages demonstrate enhanced respiratory burst activity compared with resident Kupffer cells in the rat. Gastroenterology. 91:174-181.

27. Arthur, M. J. P., S. L. Friedman, F. J. Roll, and D. M. Bissell. 1989. Lipocytes from normal rat liver release a neutral metalloproteinase that degrades basement membrane (type IV) collagen. J. Clin. Invest. 84:1076-1085.

28. Keating, M. T., and L. T. Williams. 1987. Processing of the platelet-derived growth factor receptor. J. Biol. Chem. 262:7932-7937.

29. Bienkowski, R. S., M. J. Cowan, J. A. MacDonald, and R. G. Crystal. 1978. J. Biol. Chem. 253:4356-4363.

30. Labarca, C., and K. Paigen. 1980. A simple, rapid, and sensitive DNA assay procedure. Anal. Biochem. 102:344-352.

31. Low, R. B., J. N. Hildebran, P. M. Absher, W. S. Stirewalt, and J. Arnold. 1986. Comparison of the use of isotopic proline vs. leucine to measure protein synthesis in cultured fibroblasts. Connect. Tissue Res. 14:179-185.

32. McGowan, J. A., A. J. Strain, and N. L. Bucher. 1981. DNA synthesis in primary cultures of adult rat hepatocytes in a defined medium: effects of epidermal growth factor, insulin, glucagon, and cyclic AMP. J. Cell. Physiol. 108:353-363.

33. Friedman, S. L., F. J. Roll, J. Boyles, D. M. Arenson, and D. M. Bissell. 1989. Maintenance of differentiated phenotype of cultured rat hepatic lipocytes by basement membrane matrix. J. Biol. Chem. 264:10756-10762.

34. Escobedo, J. A., M. T. Keating, H. E. Ives, and L. T. Williams. 1988. Platelet-derived growth factor receptors expressed by cDNA transfection couple to a diverse group of cellular responses associated with cell proliferation. J. Biol. Chem. 263:1482-1487.

35. Gale, R. P., R. S. Sparkes, and D. W. Golde. 1978. Bone marrow origin of hepatic macrophages (Kupffer cells) in humans. Science (Wash. DC). 201:937-938.

36. Mezey, E., J. J. Potter, R. J. Slusser, and W. Abdi. 1977. Changes in hepatic collagen metabolism in rats produced by chronic ethanol feeding. Lab. Invest. 36:206-214.

37. Rubin, K., G. K. Hansson, L. Ronnstrang, L. Claesson-Welsh, B. Fellstrom, A. Tingstrom, E. Larsson, and L. Klareskog. 1988. Induction of b-type receptors for platelet-derived growth factor in vascular inflammation: possible implications for development of vascular proliferative lesions. Lancet. i:1353-1356.

38. Rubin, K., L. Terracio, L. Ronnstrand, C. H. Heldin, and L. Klareskog. 1988. Expression of platelet-derived growth factor receptors is induced on connective tissue cells during chronic synovial inflammation. Scand. J. Immunol. 27:285-294.

39. Matsui, T., M. Heidaran, T. Miki, N. Popescu, W. La Rochelle, M. Kraus, J. Pierce, and S. Aaronson. 1988. Isolation of a novel receptor cDNA established the existence of two PDGF receptor genes. Science (Wash. DC). 243:800-804.

40. Hart, C. E., J. W. Forstrom, J. D. Kelly, R. A. Seifert, R. A. Smith, R. Ross, M. J. Murray, and D. F. Bowen-Pope. 1988. Two classes of PDGF receptor recognize different isoforms of PDGF. Science (Wash. DC). 240:1529-1531.

41. Seifert, R. A., C. E. Hart, P. E. Phillips, J. W. Forstrom, R. Ross, M. J. Murray, and D. F. Bowen-Pope. 1989. Two different subunits associate to create isoform-specific platelet-derived growth factor receptors. J. Biol. Chem. 264:8771-8778.

42. Bowen-Pope, D. F., C. E. Hart, and R. A. Seifert. 1989. Sera and conditioned media contain different isoforms of platelet-growth factor (PDGF) which bind to different classes of PDGF receptor. $J$. Biol. Chem. 264:2502-2508.

43. Terracio, L., L. Ronnstrand, A. Tingstrom, K. Rubin, L. Claesson-Welsh, K. Funa, and C.-.H. Heldin. 1988. Induction of platelet-derived growth factor receptor expression in smooth muscle cells and fibroblasts upon tissue culturing. J. Cell Biol. 107:1947-1957.

44. Davis, B. H., and A. Vucic. 1988. The effect of retinol on Ito cell proliferation in vitro. Hepatology (Baltimore). 8:788-793.

45. Gressner, A. M., and R. Haarmann. 1988. Regulation of hyaluronate synthesis in rat liver fat-storing cell cultures by Kupffer cells. $J$. Hepatol. (Amst.). 7:310-318.

46. Shiratori, Y., T. Ichida, A. Geerts, and E. Wisse. 1987. Modulation of collagen synthesis by fat-storing cells, isolated from CC14- or vitamin A-treated rats. Dig. Dis. Sci. 32:1281-1289.

47. Maher, J. J., D. M. Bissell, S. L. Friedman, and F. J. Roll. 1988. Collagen measured in primary cultures of normal rat hepatocytes derives from lipocytes within the monolayer. J. Clin. Invest. 82:450-459.

48. Friedman, S. L., and M. J. P. Arthur. 1988. Characterization of lipocyte stimulating factor (LSF): a low molecular weight species with fibrogenic and proliferative activity released by cultured rat Kupffer cells. Hepatology (Baltimore). 8:1231. (Abstr.) 